\title{
Management by Monitoring
}

\section{Land EKG ${ }^{\circledR}$ monitoring approach helps variety of users assess rangeland health.}

\author{
By Charles Orchard and Chris Mehus
}

I $n$ response to greater awareness of environmental legislation, statutory requirements and public land management concerns, public and private land managers have shown increased interest in practical monitoring techniques for evaluation of rangelands. Potential economic incentives through carbon sequestration in rangeland suggest that monitoring information may soon have direct financial benefit (Rosenberg et al. 1998).

Unfortunately, land managers in both public and private sectors have yet to agree on an effective and standard method for monitoring rangeland resources. In 1994, the National Research Council recommended assessment of rangeland health via multiple indicators of basic ecosystem processes. However, no monitoring tool or methodology was suggested.

To meet this need, rancher Charles Orchard developed Land EKG ${ }^{\circledR}$, a tool to evaluate and graphically portray land health information based upon a rapid assessment of ecological processes. The Land EKG system is intended to satisfy the monitoring needs of a wide range of potential users, including ranchers, conservation groups, land management agencies, and scientists. Three aspects differentiate Land EKG from other methods:

1) speed and efficiency;

2) ability to interpret and "communicate" relative land health; and

3 ) capacity to direct management decisions in relation to goals targeted by the resource manager.

In our present "Information Age", scant information from the land itself is readily available to on-the-ground managers. Management decisions are often based upon human resource demands, rather than the condition of the resource. Further, resource assessments generally involve judgments by individuals from diverse backgrounds, education levels and agendas (Risser 1989). Public opinion and acceptance often seem to be factors in decisionmaking. Land managers and other interested parties need a common means to evaluate rangeland health, in order to make responsible management decisions (NRC 1994).

\section{A Brief History}

For nearly a century, range professionals and scientists have been developing assessment tools to evaluate the use and relative health of rangelands. Range deterioration was first documented in the late 1800's and early 1900 's, about the time of establish- ment of the national forests. These first assessments were used to determine the suitability of western lands for grazing (NRC 1994). Jardine and Anderson (1919) introduced the first comprehensive vegetative survey method. Standing (1933) refined this method through addition of a measured production value. Meanwhile, Clements (1916) and Sampson (1917, 1919) proposed the theories of plant succession and climax states and applied them to rangeland vegetative communities. Their efforts incorporated plant community dynamics into evaluations of rangeland health. Dyksterhuis (1949, 1958) furthered the concept of a climax community through definition of a range site. Most rangeland monitoring techniques are based on one or more of these models.

\begin{tabular}{|ll|}
\hline Definitions Sidebar & \\
\hline Biological State & $\begin{array}{l}\text { The abundance, diversity, and balance of plants and animals in an } \\
\text { ecosystem. }\end{array}$ \\
A land area defined by specific physical characteristics that pro- \\
duce a distinct plant community and amount of vegetation in re- \\
sponse to management. \\
The combined processes of mineral and water cycling, energy \\
flow, which together with the biological state maintain the struc- \\
ture, organization, and activity of an ecosystem. \\
The conversion of sunlight to plant and animal matter; a key eco- \\
logical process. \\
Mineral Cycle & $\begin{array}{l}\text { The flow of nutrients such as nitrogen and phosphorus through the } \\
\text { physical and biotic components of the environment. } \\
\text { Change and development in plant communities. }\end{array}$ \\
Plant Community & $\begin{array}{l}\text { The degree to which the integrity of the soil, vegetation, water, and } \\
\text { air, as well as the ecological processes of the rangeland ecosystem, } \\
\text { are balanced and sustained. } \\
\text { The process of change and development in communities of living } \\
\text { Rangeland Health }\end{array}$ \\
organisms within an ecosystem. \\
The capture, storage and redistribution of precipitation.
\end{tabular}


In recent years, interest in range monitoring has been driven by scientific curiosity, economic need, environmental concerns and legal mandates (NRC 1994). Further, new efforts to offset global carbon emissions with sequestration in land are dependent on monitoring data (Rosenberg et al. 1998). The potential for monitoring information to impact the lives of landowners and managers is increasingly apparent.

However, even though scientists and state and federal agencies have been among the primary users of monitoring tools, multiple and changing monitoring techniques, applications, and policies have produced inconsistent data. According to the NRC (1994): The fact that it is impossible, with current methods and with current data, to determine whether federal and nonfederal rangelands are improving or degrading is itself cause for concern.

While a small percentage of private landowners have adopted range-monitoring programs, collected data are rarely applied to management decisions directly (Orchard 1996, Skovlin 2000). The challenge remains to develop and adopt a scientifically-based and practical range-monitoring technique that is widely accepted by resource managers and readily employed to make sound management decisions.

In 1994, the National Academy of Science published Rangeland Health New Methods to Classify, Inventory and Monitor Rangelands (NRC 1994). This publication contains the National Research Council's "Committee Report on Rangeland Classification", which describes an approach for evaluating the ecological health of rangeland ecosystems. The Committee identified the need for a common means of evaluation of rangeland health and recommended assessment based upon multiple indicators of basic ecosystem processes (Table 1).

It also recommended that determination of lands as "healthy," "at risk," or "unhealthy" be based on the interaction of multiple factors, rather than ev-
Table 1. Ecological processes and indicators to use for range health assessment (NRC 1994).

\begin{tabular}{lll}
\hline \hline \multicolumn{1}{c}{ SOIL } & \multicolumn{1}{c}{ DISTRIBUTION OF NUTRIENT } & RECOVERY MECHANISMS \\
STABILITY/WATERSHED & CYCLING AND ENERGY FLOW & \\
\hline 1. A horizon & 1. Distibution of plants & 1. Age class distribution \\
2. Pedestaling & 2. Litter distribution/incorporation & 2. Plant vigor \\
3. Rills and gullies & 3. Root distribution & 3. Germination mico-site \\
4. Scouring/sheet erosion & 4. Distribution of photosynthesis & \\
5. Sedimentation/dunes & & \\
\hline
\end{tabular}

idence from single indicators (Table 2). However, the Committee did not present a monitoring tool or methodology for this purpose.

\section{How Land EKG Works}

In response to the report of the National Research Council, fourth generation rancher and Montanabased range consultant Charles Orchard developed a tool to evaluate and portray information on rangeland health based on a rapid ecological assessment protocol. This tool is called Land EKG and was first developed in 1994. After testing and revision by university scientists, agency (BLM, USFS, NRCS) field staff and ranchers in nine western states, the midwest and Canada, Land EKG has become a sophisticated and efficient diagnostic tool for responsible land management.

Monitoring several fundamental ecosystem processes appears to be the most suitable and appropriate means to determine the effects of land management practices (SRM 1991, NRC 1994). Multiple indicators, consistent criteria and consistent methods of data interpretation have been identified as requirements for an effective and broadly applicable monitoring system
(NRC 1994, Breckenridge et al. 1995, Smith et al. 1995).

Four basic ecosystem processes are of concern in assessing the condition of natural landscapes: mineral cycle, water cycle, plant community function (succession), and energy flow. How well these processes are functioning determines in large measure: 1) the amount and availability of nutrients that cycle through living users of the landscape; 2) the ability of the soil to capture, store and supply water to plants and aquifers; and 3) the ability of the landscape to capture solar energy and convert it into food substrates for other organisms.

For a monitoring system to be broadly applied and accepted, it must provide meaningful data, and also be relatively fast, ecologically valid, and easy to learn and use. Practicality and function have driven the development of the Land EKG system. Land EKG considers 22 associated indicators of ecological processes (Figure 1). These indicators construct a sequence of evidence for evaluation of land health in a manner meaningful to hands-on land managers.

Although monitoring sites may be selected at random, the authors en-
Table 2. Excerpt of Rangeland Health Evaluation Matrix (NRC 1994).

\begin{tabular}{llll}
\hline \hline INDICATOR & \multicolumn{1}{c}{ HEALTHY } & \multicolumn{1}{c}{ AT RISK } & UNHEALTHY \\
\hline A Horizon & $\begin{array}{l}\text { Fresent and distribution } \\
\text { unfragmented }\end{array}$ & $\begin{array}{l}\text { process of water cycling } \\
\text { Present but fragmented } \\
\text { distribution developing }\end{array}$ & $\begin{array}{l}\text { Absent, or present } \\
\text { only in association with } \\
\text { prominent plants }\end{array}$ \\
Pedestaling & $\begin{array}{l}\text { No pedestaling of plants or } \\
\text { rocks }\end{array}$ & $\begin{array}{l}\text { Pedestals present, but on } \\
\text { mature plants only }\end{array}$ & $\begin{array}{l}\text { Most plants and rocks } \\
\text { pedestal }\end{array}$ \\
$\begin{array}{l}\text { Rills and } \\
\text { gullies }\end{array}$ & $\begin{array}{l}\text { Absent, or with blunted } \\
\text { and muted features }\end{array}$ & $\begin{array}{l}\text { Evidence of small } \\
\text { erosional patterns }\end{array}$ & $\begin{array}{l}\text { Well defined, actively } \\
\text { expanding erosional } \\
\text { features }\end{array}$ \\
\hline
\end{tabular}




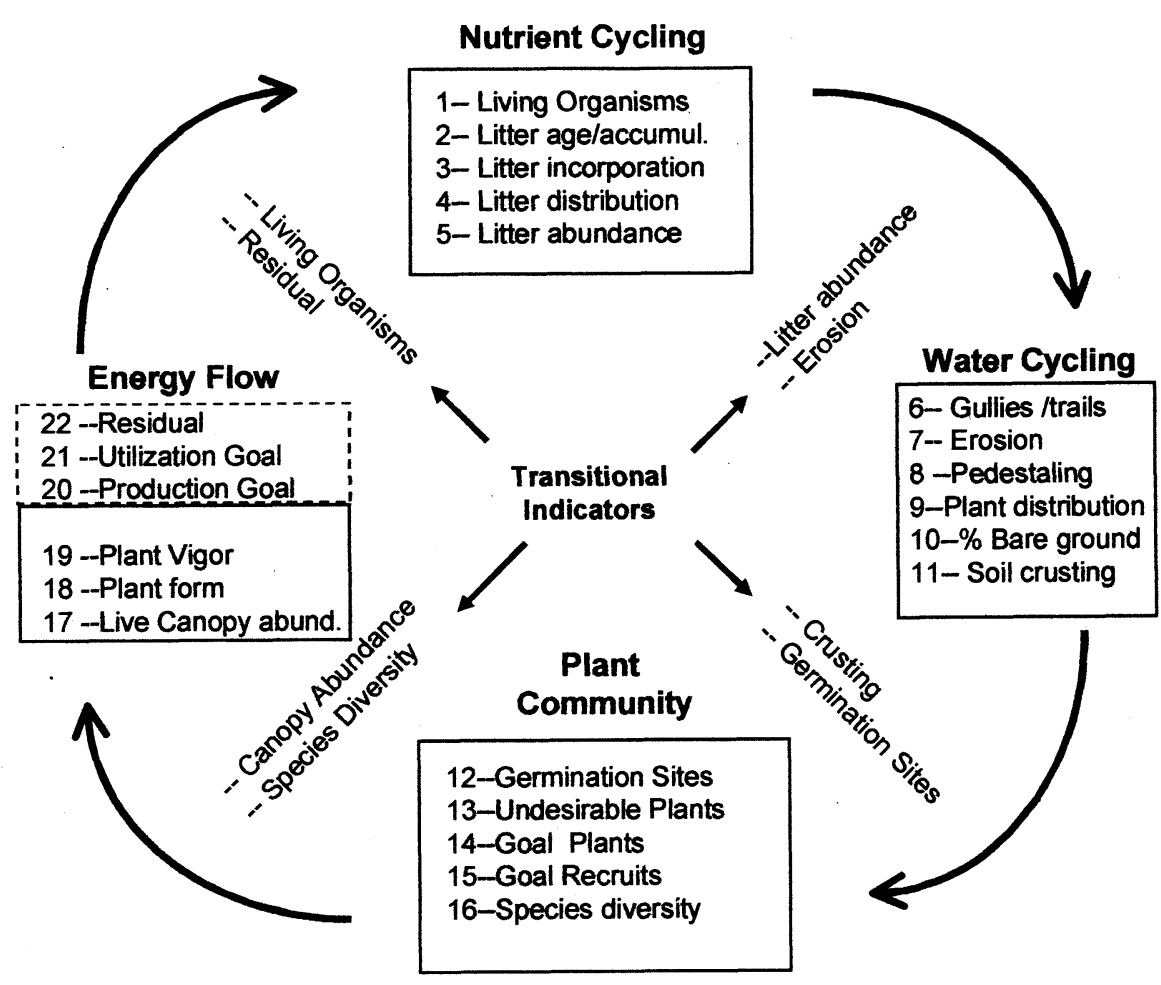

Fig. 1. Ecological processes and associated indicators upon which Land EKG ${ }^{\circledR}$ monitoring is based.

courage managers to choose locations based upon their relevance to management decisions. A monitoring site may be chosen for one or more of the following reasons: 1) to establish baseline data, 2) to represent a larger land area, 3) to be easily relocated, 4) to reflect response to management change, 5) to track special concern areas or, 6) to establish site potentials for other areas of land. Once a general site is identified, a transect starting point may be randomly located. The transect line should be oriented in an eastwest direction to avoid unwanted shadows in photo-monitoring.

\section{Three Levels Of Monitoring}

Land EKG monitoring is intended to satisfy a wide range of potential users, from landowners to agency personnel and scientists. In order to meet the different needs of these groups, three levels of monitoring have been designed. Each level considers the same indicators, but with increasing detail, rigor, and repeatability (Fig 2).

Level I (EZ-EKG $\left.{ }^{\circledR}\right)$ is the most sults of these indicators on an evaluation card, the user creates an immedi- ate display of ecological function that can be used to determine management recommendations in the field. Time requirements for this field assessment are less than 1/2 man-hour using the EZ-EKG Field Card.

The Level 2K Rancher Land EKG is appropriate for permanent monitoring of land resources. This level is an expanded version of the EZ-EKG. First, monitoring objectives are developed relative to management goals and time constraints. Then, potential monitoring sites are identified with the aid of a program development model. Finally, in the field, permanent transects (200 ft.) are located to represent management areas, plant communities and/or landform types. Users are encouraged to utilize resources such as NRCS Soil Surveys to determine site potentials for transect locations.

Four "hoop points" are randomly (or non-randomly) located along each transect. Each hoop point is marked, photographed, and recorded for use in future monitoring. Field measurements and evaluations are considered in three zones (Figure 3). The smallest area or "hoop zone" $\left(4.8 \mathrm{ft}^{2}\right)$ is the most closely scrutinized area, in which 22 ecological indicators are evaluated. In Zone II (Hoop Zone x 100) plant community composition and specific faunal activity (e.g. signs of insects, herbivory, scat, burrows, tracks, wildlife calls and sightings) are assessed. The Transect Zone ( \pm 1-3

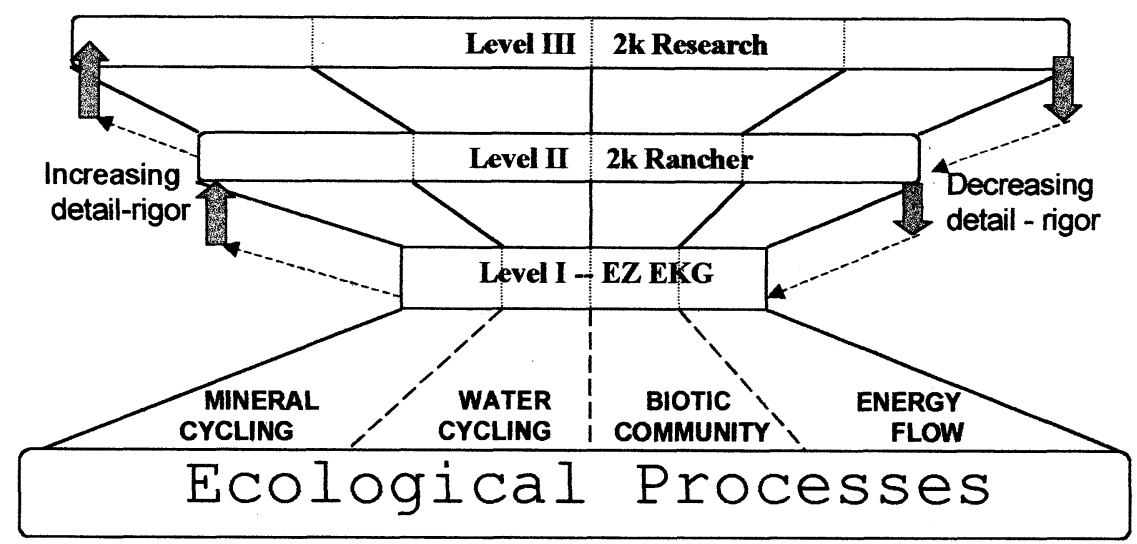

Fig. 2. Hierarchical structure of Land EKG ${ }^{\circledR}$ assessment levels. 


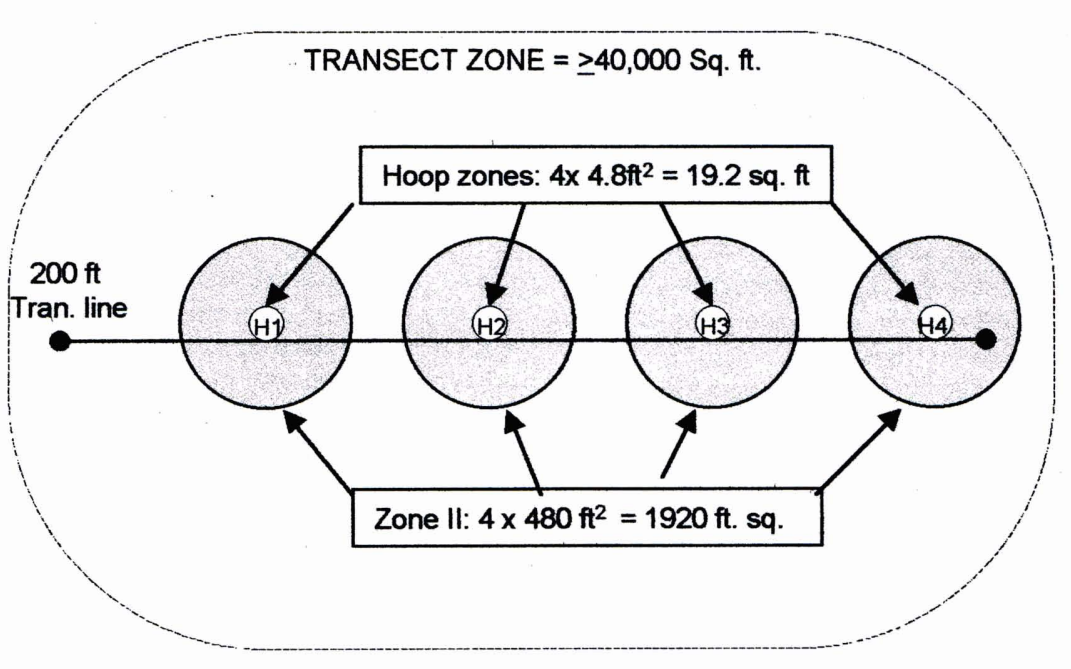

Fig. 3. Zones of observation used with the $2 \mathrm{~K}$ Rancher Land EKG ${ }^{\circledR}$.

acres) is examined for floral species richness (i.e. the number of species present), gross erosional information, forage production, and estimated forage residual.

Scoring decisions within the Hoop Zones are simplified through use of the Land EKG Field Data Form, which allows comparison of the characteristics found within each Hoop Zone to an 11-point matrix chart. The Field Matrix contains detailed descriptions of each indicator that determine a condition score ranging from "non- function" to "optimum function". Ten of the 22 indicators evaluated are quantitative. In addition to these indicators, the user estimates plant species composition by weight and identifies the presence or absence of goal and non-goal plants. In addition, historic use, weather conditions, current management, and physical site parameters are recorded to help interpret the condition found. Time requirements are $\leq$ 4 man-hours to set up a site (place transect \& collect data) with subsequent assessments averaging $\leq 1 / 2$ man-hour.

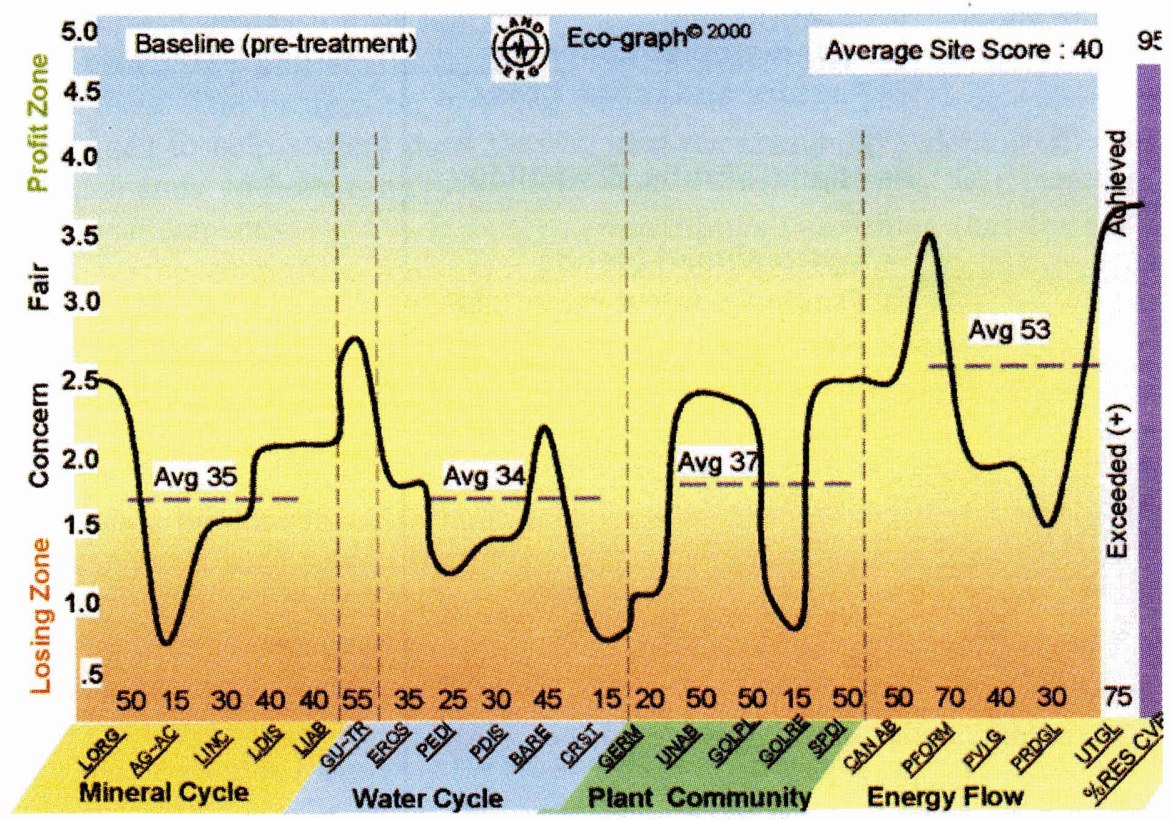

Fig. 4. Example of Level II Land EKG ${ }^{\circledR}$ Eco-graph.
Field data are quickly tabulated, scored, and plotted by the user to create a Land Eco-graph that shows a "point-in-time" view of land health (Figure 4). Finally, a step-wise analytical procedure is used to identify potential management options to address concerns. Successive eco-graphs in future years identify ecological trends to the land manager.

The Level III Research Land EKG is more elaborate than the other levels and is still in the testing phase. In this level, the statistical significance of field data is improved through a greater number of observation points. Expanding the number of observations, as well as inclusion of additional physical, chemical, and ecological parameters adapts the system to meet increasing levels of rigor.

\section{Land EKG ${ }^{\circledR}$ in Use}

The mission of Land EKG, Inc. is to help land managers optimize solar profit by creating healthy soil systems with diverse biological communities. Since 1994, the Land EKG method has been trialed and applied by more than 500 landowners, agency staff, and university personnel across 11 states. The technique has been used on public (BLM, USFS, state-owned) and private grazing lands, bison and elk range, conservation properties and mine reclamation sites. It has also been used successfully to establish "common ground" among land managers in the US and Canada. We estimate that Land EKG is now in use on over one million private acres in the US and Canada.

Land managers need a standard and uniform procedure for assessment of rangeland. Experts indicate an ecosystem process perspective creates the best opportunity for successful land management and monitoring. The Land EKG methodology is derived from accepted assessment tools. Its efficiency and user-friendly design make Land EKG a practical tool for a wide range of users.

-Land EKG is a registered trademark owned by Land EKG Inc.- 
The authors are respectively, a ranch owner/re source management consultant based in Bozeman MT, 6085 Browning Ln. 59718, (406)-582-7480 and a ranch / field technician based in Big Timber Mont. Authors wish to acknowledge Abigail Breuer for her contribution and suggestions dur ing the preparation of this manuscript.

\section{References}

Breckenridge, B., W. Kepner, and D. Mouat. 1995. A process for selecting indicators for monitoring conditions of rangeland health, pp. 45-59. Washington, DC: US Department of Energy.

Clements, F.E. 1916. Plant succession: An analysis of the development of vegetation. Carnegie Inst., Pub 520. Washington, DC: Carnegie Institute.

Dyksterhuis, E.J. 1949. Condition and management of rangeland based on quantitative ecology. J. Range Manage. 2:104-115

Dyksterhuis, E.J. 1958. Ecological principles in range evaluation. Bot. Rev. 24:253272

Jardine, J.T., and M. Anderson. 1919. Range Management on the National Forests. USDA Bulletin 790, pp 16-23. Washington, DC: US Dept. of Agriculture.
National Research Council. 1994. Rangeland Health - New methods to classify, inventory, and monitor rangelands. Washington, DC: National Academy Press.

Orchard, C. 1996. An evaluation and documentation of holistic resource management practices on northern Rocky Mountain ranches. MS thesis. Montana State University, Bozeman.

Risser, P. 1989. Range condition analysis: Past, present and future. In: Secondary succession and the evaluation of rangeland condition (eds. W. Lauenroth and W. Laycock), pp 143-156. Boulder Colo: Westview Press.

Rosenberg, J., R. Izaurralde, and E. Malone. 1998. Carbon sequestration in soils: science, monitoring, and beyond. Proceedings of the St. Michaels, MD workshop, December 1998. Columbus Ohio, Battelle Press

Sampson, A.W. 1917. Succession as a factor in range management. Journal of Forestry. 15: 593-596.

Sampson, A.W. 1919. Plant succession relation to range management. In: USDA Technical Bulletin No. 791, pp. 1-76. Washington, DC: US Dept. of Agriculture.
Savory, A. 1988. Holistic Resource Management. pp. 66-108. Washington, D.C. Island Press.

Skovlin, S. 2000. Assessing rangelands: A comparison of two current methods. MS thesis, Montana State University, Bozeman, Mont.

Smith, L., P. Johnson, G. Ruyle, and Task Group Concepts and Terminology Committee members. 1995. New concepts for assessment of rangeland condition. J. Range Manage. 48:271-282.

Society for Range Management. 1991. New directions in range condition assessment. Task group on unity in concepts and terminology. Rep. to the Board of Directors. Denver, Colo., Society for Range Management.

Standing, A.R. 1933. Ratings of forage species for grazing surveys based on volume produced. Utah Juniper. 4:11-16.

US Department of the Interior. 2000. Technical Reference 1734-6 Version 3. Interpreting Indicators of Rangeland Health, Version 3.

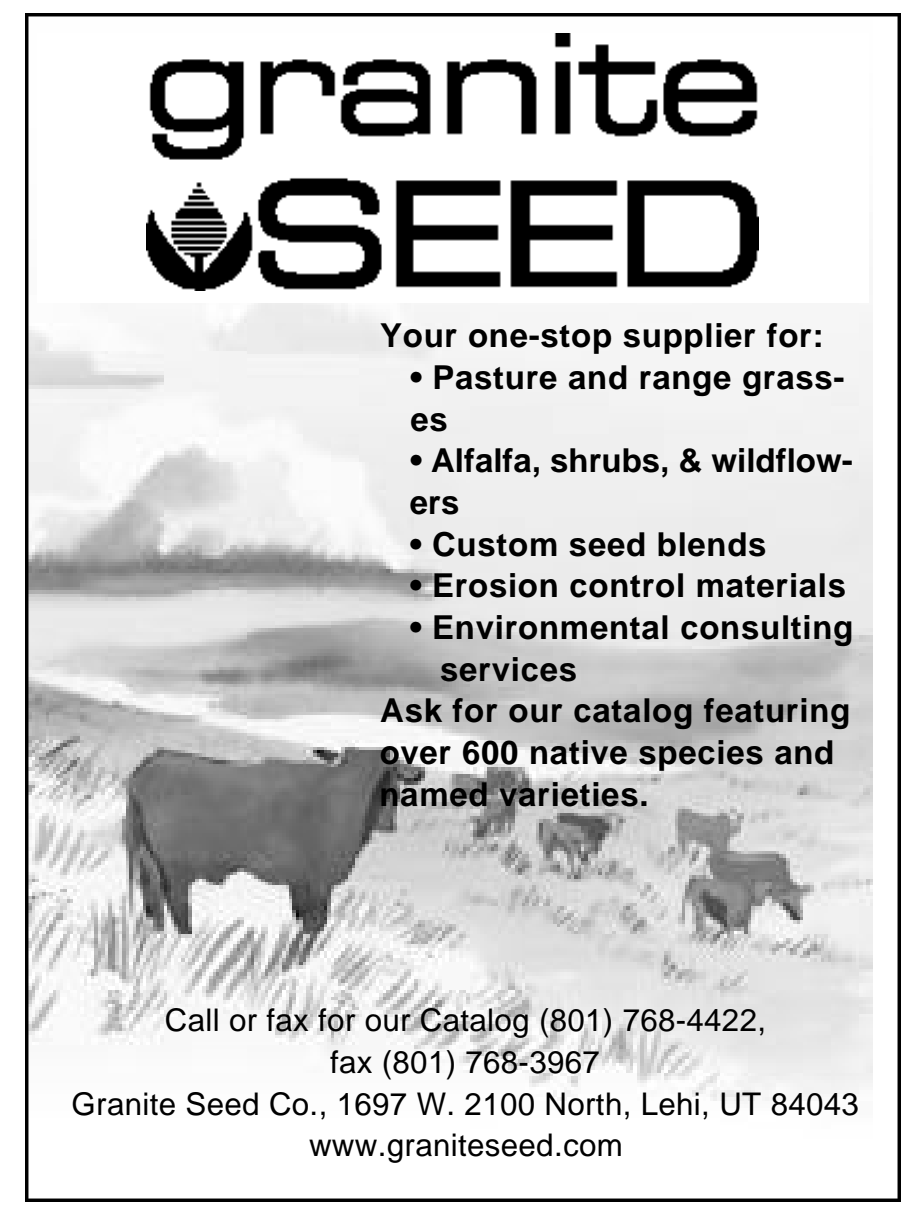

